\title{
Luovuus yrittäjyyskasvatuksen haasteena
}

MARJA-LIISA KAKKONEN

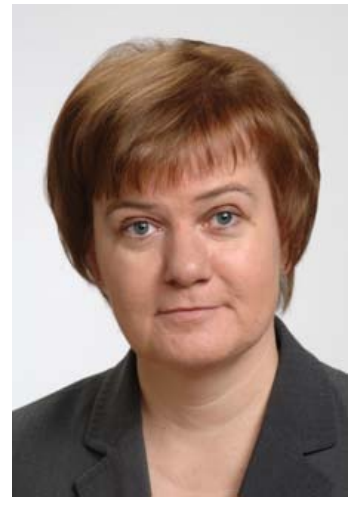

L Luovuudella voidaan tarkoittaa hyvin monenlaisia asioita. Lähtökohtaisesti luovuus on kyky tuottaa jotain uutta, erilaista ja käytännössä hyödynnettävää (Sternberg \& Lubart 2003). Luovuutta tarkastellaan yleensä kirjallisuudessa lopputuloksen, prosessin tai yksilön näkökulmasta. Lisäksi luovuus on kontekstisidonnaista eli toimintaympäristöllä on suuri merkitys yksilön luovuuden käytössä. (Tuomivaara, Hynninen, Leppänen, Lundell \& Tuominen 2005). Itse asiassa luovuus ja sen hyödyntäminen on yksi olennaisimmista asioista, joka erottaa ihmisen muista lajeista (Ko \& Butler 2007). Psykologit pitävät luovuutta yksilön henkisenä prosessina ja luovuutta pidetään osittain perinnöllisenä ja osittain harjaantumisen tuloksena. Kuitenkin luovuuteen liittyy myös kulttuurinen ja sosiaalinen näkökulma. Tämän vuoksi luovuutta tulisi tarkastella näiden kolmen vuorovaikutuksessa ja näkökulmasta (yksilö, kulttuuri ja vuorovaikutus). Lisäksi pelkistetysti voidaan esittää, että yksilön luovuus ilmenee käytännössä vasta, kun hän muuttaa toimintaympäristöään (Csikszentmihalyi 2003).

Ammatillisesti yksilön luovuus liittyy asiantuntijuuteen, luovaan ajatteluun ja motivaatioon hyödyntää luovuutta (Kuvio 1). Asiantuntijuus sisältää teknistä, toiminnallista ja älykkyyteen perustuvaa tietoa. Kyky luovaan ajatteluun määrittää, miten joustavasti ja kekseliäästi ihminen lähestyy ongelmia. Motivaatio luovuuden hyödyntämiseen puolestaan syntyy eri tavoin: sisäinen intohimo käsillä olevan ongelman ratkaisuun johtaa kuitenkin yleensä paremmin luoviin ratkaisuin kuin ulkoiset palkkiot. (Amabile 2001).

Yrittäjyyttä voidaan lähestyä laaja-alaisesti ajattelu-, toiminta- ja suhtautumistapana, joka saa omat ja yhteisön voimavarat toimimaan. Yrittäjyys on myös tavoitteellista ja omavastuista toimintaa.

LUOVUUS

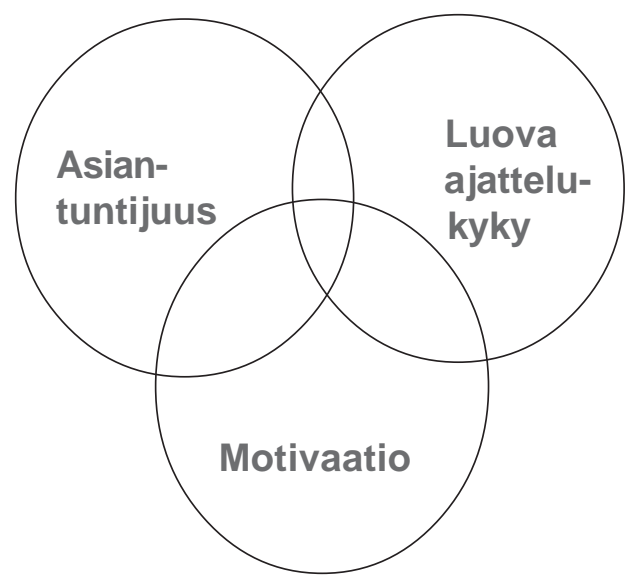

KUVIO 1: Luovuuden kolme komponenttia (Amabile 2001, 4) 
(Koiranen \& Peltonen 1995). Yrittäjyys on synnynnäisen (esimerkiksi luonteenpiirteet) ja opitun yhteisvaikutusta (kasvu, kasvatus ja oppiminen), ja yrittäjyyteen kulminoituvat hyvin voimakkaasti aloitekyky, työhalu, määrätietoisuus, itsenäisyys ja sitkeys (Koiranen \& Ruohotie 2001).

Kyrö (1997) jakaa yrittäjyyden ulkoiseen yrittäjyyteen, sisäiseen yrittäjyyteen ja omaehtoiseen yrittäjyyteen. Ulkoinen yrittäjyys tarkoittaa omistajayrittäjyyttä, jolloin henkilö omistaa, johtaa ja tekee työtä yrityksessään. Sisäinen yrittäjyys on organisaation sisäistä yrittäjyyttä ja omaehtoinen yrittäjyys on puolestaan yksilön yrittäjämäistä toimintaa toisen palveluksessa. (Kyrö 1997; 2001). Yrittäjyys voidaan määritellä siis monin eri tavoin, mutta olennaisin ero ẏksilön kannalta on kuitenkin siinä, tarkoitetaanko yrittäjällä henkilöä (omistajayrittäjä), joka harjoittaa itse yritystoimintaa, vai tarkoitetaanko sillä yrittäjämäisesti toimivaa henkilöä (sisäinen yrittäjä), joka on toisen palveluksessa palkattuna työntekijänä.

Yrittäjillä on yleensä hyvä ammatillinen osaamisen taso, mutta heille on tärkeitä myös useat metataidot, esimerkiksi oppimisen taito, organisointikyky, ajanhallinta ja ongelmanratkaisukyky (Koiranen \& Ruohotie 2001). Yritystoiminnan kannalta menestyvän yrittäjän tärkeimmät osaamisalueet ovat asioiden hallinta, omien voimavarojen käyttö ja ammattitaito. Lisäksi yrittäjänä toimimiseen liittyvät olennaisesti mm. luovat ongelmanratkaisutaidot, neuvottelutaidot, liiketoiminnan tai projektin kokonaisvaltainen johtaminen, strateginen ajattelu ja verkostoituminen. (Gibb 2005). Kets de Vries (1991) puolestaan yleistää varovasti, että yrittäjät ovat toiminnassaan suoritushakuisia, haluavat ottaa vastuun päätöksistään ja inhoavat rutiineja. Luovat yrittäjät ovat työssään sitkeitä ja käyttävät paljon mielikuvitustaan. Gibb (2005) esittää että yrittäjämäiseen käyttäytymiseen liitetään usein kunnianhimo ja tavoitteiden saavuttaminen, itseluottamus, sinnikkyys, toimintaorientaatio, kova työnteko, päättäväisyys ja luovuus.

Yrittäjämäinen luovuus tarkoittaa uusien ja hyödyllisten ideoiden tuottamista joko uuden tai jo olemassa olevan yrityksen yritystoiminnassa. Käytännössä se liittyy joko suoraan joko uusiin tuotteisiin tai palveluihin, uusien markkinoiden tunnistamiseen nykyisille tuotteille tai palveluille, uusien toimintatapojen löytämiseen tai uusiin tapoihin hankkia resursseja tuotteiden tai palveluiden tuottamiseksi. (Amabile 1997). Kuitenkin näiden toteuttamiseen yritystoiminnassa liittyy yleen- sä myös taloudellinen riski ja epävarmuus sekä sen myötä menestymisen tai menestymättömyyden mahdollisuus (Koiranen \& Peltonen 1995). Riskin merkitystä yritystoiminnassa voidaan kuvata siten, että se on olennainen osa yrityksen toimintaa. Yritystoimintaa harjoitetaan voiton tavoittamiseksi ja voiton kääntöpuolella on riski eli epäonnistumisen mahdollisuus. Riski liittyy siis epävarmuuteen. Näin ollen riski voidaan ymmärtää taloudellista riskiä laajemmin eli epävarmuudensietokykynä ja esimerkiksi Kyrö (2006) on tutkinut opiskelijoiden riskisietokykyä nimenomaan erävarmuuden sietokyvyn näkökulmasta. Näin ollen luovuuden ja riskinottohalukkuuden merkitys ja yhteyden tunnistaminen ei ole tärkeää pelkästään yritystoiminnassa, vaan olennaista myös yrittäjyyskasvatuksessa.

\section{Yrittäjyyskasvatuksen tavoitteet ja sisältö}

Uudet pedagogiset käsitykset oppimisesta ja yhteiskunnan muutokset ovat muuttaneet voimakkaasti koulutusjärjestelmän tavoitteita ja työelämän vaatimuksia. Tämän myötä yrittäjyyskasvatuksen toteuttaminen vaatii monia merkittäviä muutoksia aikaisempiin käytäntöihin verrattuna. (Leskinen 1999). Kuitenkin yrittäjyysopetuksen tavoitteet voivat olla hyvin erilaisia: 1) yrityksen perustaminen tai pk-yrityksen johtamisen edistäminen, 2) yrittäjyyteen ja yritystoimintaan liittyvän tiedon lisääminen ja 3) yrittäjämäisten toimintatapojen lisääminen. (Paasio ja Nurmi 2006). Lisäksi on tärkeää huomata, että yrittäjyys voi kanavoitua muutakin kautta kuin liiketoiminnan aloittamisena. "Yrittäjämäinen toiminta" ilman ulkoiseen ja sisäiseen yrittäjyyteen liittyviä yritystoiminnan omistussuhteita tarjoaa yrittäjyys-määritelmän, joka soveltuu koulun ja sen opetussuunnitelmien mukaiseen yrittäjyyskasvatuksen perustaksi. Näin ollen koulun yrittäjyyskasvatus ei ole suoraa pyrkimystä vaikuttaa yritysten määrän kehitykseen, vaan yksilön yrittäjämäiseen käyttäytymiseen tai toimintatapaan. (Ristimäki 2004a)

Lisääntyvä yrittäjyysopetus edellyttää entistä suurempaa määrää yrittäjyyden ymmärtäjiä ja osaajia ja se asettaa vaatimuksia opetusmenetelmien ja pedagogiikan kehittämiselle. Yrittäjyysopintojen erityislaatuisuudessa ei painotu niinkään opetettava sisältö, vaan oppimis- ja opetustavat. Koska yrittäjyyteen liittyvien tietojen ja taitojen opettaminen ei automaattisesti lisää yrittä- 
jyysaktiivisuutta yrittäjäksi ryhtymiseen, yrittäjyysopintojen toteutuksessa on olennaista pohtia opetuksen tavoitteita ja käydä sen perusteella keskustelua opetuksen sisältöjen ja menetelmien kanssa. (Paasio ja Nurmi 2006).

Yrittäjyyskasvatuksen laaja-alaisuus asettaa erityisesti odotuksia korkeakoulupedagogiikalle, joka on perinteisesti painottanut tietoa ja tietämistä. Esimerkiksi 1990-luvulta alkaen yrittäjyyskasvatuksen opettamisen muoto on ollut liiketoimintasuunnitelman laatiminen. Kuitenkin tämäntyylisen pedagogisen lähestymistavan mahdollisuudet tavoittaa aidosti yrittäjämäinen oppiminen voidaan kyseenalaistaa, mutta sen tiedostamista voidaan pitää uusien käytäntöjen kehittämisen ensimmäisenä vaiheena. (Kyrö \& Ripatti 2006).

Ristimäen (2004b) mukaan yrittäjyyskasvatus etenee vaiheittain. Siinä voidaan erottaa neljä eri tasoa. Ensimmäisellä tasolla yrittäjyyskasvatusta pidetään lähinnä kaupallisten aineiden opettamisena. Osa opettajakunnasta kokee nämä edelleen yhtenä ja samana asiana. Toinen taso edustaa yrittäjyyskasvatuksen tuntemuksen ja ymmärryksen kehittymistä ja kolmas taso kuvaa puolestaan vaihetta, jolloin yrittäjyyskasvatus nähdään enemmän opetuksen metodisena kuin sisällöllisenä aihealueena. Tällöin yrittäjyys määritellään kasvatustoimintana, jonka kautta pyritään osallistumaan yksilön persoonan, ominaisuuksien ja toimintatavan kehittymiseen. Neljäs taso kuvaa pyrkimystä ymmärtää yrittäjyyskasvatus laajana koko yhteisöä koskevana sosiaalistavana tehtävänä, jossa koko koulussa ja sen toimintakulttuurissa on otettu huomioon yrittäjyyskasvatuksen tavoitteet ja niiden toteutuminen. Esimerkiksi liiketalouden opintoja tarjoavien koulujen ("businesskoulut") ei pitäisi enää painottaa niin paljon liiketoiminnan suunnittelua tai pienyritysten johtamista, vaan luovuutta ja muutosta. Kouluilla on selvä tarve kehittää enemmän yrittäjämäisesti käyttäytyviä yksilöitä. (Kirby 2004).

Paajanen (2001) esittää yrittäjyyskasvattajan ideaalimallin, jonka mukaan opettajan tulee itse työskennellä yrittäjämäisesti. Toisin sanoen opettajan yrittäjämäinen toimintatapa on luovaa ja dynaamista ja sisältää halun ottaa riskejä, tarvittaessa kovaa työntekoa, kaiken kaikkiaan vastuullisen ja motivoituneen työskentelytavan. Lisäksi ideaalimallin yrittäjyyskasvattajalla on positiivinen asenne yrittäjyyttä kohtaan ja hän ymmärtää yrittäjyyden kokonaisvaltaisena ilmiönä, jolloin yrittäjyyskasvatus tarkoittaa liike-elämässä tarvitta- vien tietojen, taitojen ja asenteiden kehittämistä. Ideaalimallin yrittäjyyskasvattaja on itse omaksunut nykyaikaiset opetusmenetelmät, joilla hän aktivoi ja kannustaa opiskelijoita yrittäjyyteen ja sosiaaliseen kanssakäymiseen. (Paajanen 2001). Luukkainen ja Wuorinen (2002) esittävät, että yrittäjyyskasvatuksessa on kyse pohjimmiltaan kahdesta asiasta: 1) sen tiedostamisesta, että yrittäjyyskasvatuksen tavoitteet liittyvät myös yrittäjämäiseen elämän- ja työasenteeseen ja että niillä on keskeinen merkitys sekä toimittaessa yrittäjänä että työskenneltäessä toisen palveluksessa ja 2) yrittäjyyskasvatus on pedagogisia valintoja. Olennaista on opettajan tekemät pedagogiset ratkaisut ja niiden ohjaavuus esimerkiksi mallina toimimisen kautta. Opettajan tekemät opetusratkaisut ovat keskeisiä asioita yrittäjämäisten ominaisuuksien kehittymisen ja sisäistämisen kannalta.

Vaikka yrittäjyys on melko nuori tieteenala, nykyään voidaan yrittäjyyden opetuksessa pitää seuraavia olettamuksia jo "itsestään selvyyksinä”: yrittäjyyttä voi oppia, yrittäjyyttä voidaan opettaa tavoitteellisesti ja yrittäjyyskoulutusta voi hankkia myös akateemisella tasolla ja "businesskouluissa”. Olennaista on kuitenkin pohtia, kuka yrittäjyyttä opettaa (yrittäjyysvalmiuksien näkökulmasta), mitä opetetaan (sisältö), miten opetetaan (metodit) ja mitä oppimistuloksia opiskelijoilta odotetaan. (Klandt \& Volkmann 2006).

\section{Luovuus opiskelijoiden \\ näkökulmasta -tapaustutkimus}

Tässä kuvatun tapaustutkimuksen tarkoituksena oli selvittää ammattikorkeakouluopiskelijoiden mielipiteitä ja kokemuksia luovuuden käytöstä heidän opinnoissaan. Siihen valittiin yksi liiketalouden opiskelijaryhmä. Opiskelijat $(\mathrm{n}=33)$ olivat nuoria aikuisia (keski-ikä noin 20 vuotta). Aineiston hankinnan metodina käytettiin itsearviointitehtävää: opiskelijoita pyydettiin kirjoittamaan essee pohtimalla seuraavia asioita: 1) Kuinka olet itse käyttänyt luovuutta opinnoissasi, 2) Minkälaisia riskejä olet ottanut hyödyntäessäsi luovuutta ja 3) Kuinka voisit lisätä luovuuden käyttöä opinnoissasi? Yrittäjyys-opintojaksolla luovuutta oli käsitelty laaja-alaisesti yritystoimintaan ja yksilön yrittäjämäiseen käyttäytymiseen liittyvänä asiana eri näkökulmista ja eri yhteyksissä. Näin ollen opiskelijoilla oli monipuolinen käsitys, mitä luovuus voi olla ja miten se ilmenee. Tehtävänannossa luovuut- 
ta ei määritelty yksiselitteisesti, vaan opiskelijoita kannustettiin kuvaamaan omakohtaisesti luovuuden ilmenemistä omien käytännön esimerkkiensä ja kokemustensa avulla.

Aineiston analyysin päävaiheet olivat seuraavat: Ensin luin kaikki esseet omina kokonaisuuksinaan. Tämän jälkeen järjestin vastaukset kysymyksittäin ja analysoin ne. Tämän jälkeen ryhmittelin kunkin kysymyksen alla olevat frekvenssit alateemoittain ja raportoin erikseen niiden painotusten mukaisessa järjestyksessä. Esittelen tulokset valittujen kysymysten mukaisesti.

\section{Luovuuden käyttö opinnoissa}

Opiskelijoiden näkemys luovuuden käytöstä vaihteli paljon. Osa opiskelijoista kertoi, että he käyttävät luovuuttaan paljon sekä oppimisen edistämisessä että suorittaessaan erilaisia oppimistehtäviä, projekteja tai muita opintoihin liittyviä toimeksiantoja. Osa opiskelijoista puolestaan kertoi luovuuden käytön olevan hyvin rajallista heidän opinnoissaan, vaikka kertoivat muutoin olevansa luovia persoonia (harrastavat musiikkia, maalaamista, piirtämistä, ym.).

Enemmistö opiskelijoista (21) kertoi luovuuden liittyvän oman opiskelunsa tehostamiseen ja uusien opiskelumetodien löytämiseen. Heistä yhdeksän opiskelijaa esitti hakevansa uusia tapoja tehostaa opiskeluaan ja oppimistaan. Kymmenen opiskelijaa esitti nimeltä hyödyntävänsä "brainstorming” tai "mindmap” -tekniikkaa. Kaksi puolestaan kertoi hyödyntävänsä visualisointia kokonaisuuksien hahmottamiseksi paremmin opiskeltavasta asiasta.

Osa opiskelijoista kertoi käyttävänsä luovuuttaan nimenomaan tehdessään eri opintojaksojen oppimistehtäviä tai projekteja, joita opettajat arvioivat osana kurssisuoritusta. Kahdeksan opiskelijaa ilmoitti soveltaneensa luovuuttaan erityisesti projekteissa ja oppimistehtävissä, joissa opiskelijalle annettiin riittävästi vapautta tehtävän toteuttamisessa. Kuusi opiskelijaa ilmoitti käyttäneensä luovuuttaan tehdessään PowerPoint-esitystä, neljä kirjoittaessaan esseetä ja kaksi kirjoittaessaan raporttia. Lisäksi yksi ilmoitti olleensa omasta mielestään luova kirjoittaessaan tentissä vastauksia esitettyihin kysymyksiin ja yksi puolestaan soveltaneensa luovuuttaan tehdessään perinteisiä piirtoheitinkalvoja esitystä varten.

Yhteensä 14 opiskelijaa kertoi hyödyntäneensä luovuuttaan erilaisissa ongelmanratkaisutilan- teissa ja yksittäisten tavoitteiden saavuttamisessa. Puolet heistä painotti uusien näkökulmien näkemisen ja hyödyntämisen merkitystä prosessin alkuvaiheessa. Osa heistä esitti luovuuden käytön liittyvän annetun tehtävän suorittamiseen määräajassa, tehtävän ratkaisuun silloin, kun siihen ei ole valmista ratkaisua, tai myöhästyneen oppimistehtävän palautuksen yhteydessä luoviin selityksiin opettajalle.

Kaksi opiskelijaa kertoi käyttäneensä luovuuttaan vilpillisellä tavalla: toinen keksi "lunttausmetodin” päästäkseen tentistä läpi, toinen plagioi oppimistehtävän osia internetistä omaan vastaukseensa. Muut yksittäiset luovuuden käyttökokemukset liittyivät ihmisten kanssa keskusteluun, vaikean tilanteen hallintaan ja nopean päätöksen tekemiseen.

\section{Riskit luovuuden hyödyntämisessä}

Opiskelijat pohtivat luovien ratkaisujen aiheuttamia riskejä, mutta myös sitä, miten epäonnistumisen mahdollisuus toimi luovan ratkaisun esteenä. Opiskelijat kertoivat riskien koskeneen joko prosessiin liittyvien muiden ihmisten reaktioita tai projektin lopputuloksia.

Koska muilla voi olla hyvinkin erilainen näkemys luovuudesta ja työstettävästä asiasta, opiskelijat kokivat riskeiksi seuraavat tekijät: muut opiskelijat tai opettaja eivät arvosta (5), eivät pidä (4), eivät ymmärrä (3) tai eivät hyväksy hänen ideaa tai ratkaisua. Kahden opiskelijan näkemyksen mukaan koko projekti sai huonon arvosanan sen vuoksi, ettei opettaja pitänyt koko ideasta. Lisäksi kaksi opiskelijaa koki, että uusi, liian luova projektin toteutustapa esti lopulta koko työn valmistumisen. Yksi opiskelijoista esitti myös, että liian monta luovaa ideaa samassa ryhmätyössä tarkoittaa liian erilaisia näkemyksiä, mikä on estänyt ryhmän yhteisen näkemyksen syntymisen kokonaan.

Luovan idean hyödyntäminen projektissa saattoi merkitä epäonnistumista lopputuloksessa. Opiskelijoille se tarkoitti seuraavia asioita: Aihe on ollut kokonaan väärä, eikä hän edes itse ole enää tyytyväinen (2), lopputuloksella ei ollut mitään yhteyttä todelliseen elämään (2), työ oli liian vaikea toteuttaa (4) ja projekti tuli liian kalliiksi (1). Lisäksi kaksi opiskelijaa kertoi käyttäneensä uutta opiskelumetodia ja epäonnistuneensa siinä. Vilpillisesti luovuuttaan käyttänyt opiskelija kertoi jääneensä kiinni oppimistehtävän plagioinnista.

Ottamiensa riskien lisäksi opiskelijat pohtivat 
esteitä sille, miksi eivät ole hyödyntäneet luovia ideoitaan enemmän opinnoissaan. Tulokset jakaantuivat kahteen osaan: koulutukseen liittyvät esteet (24) ja sosiaaliset esteet (12). Koulutuksellisiin esteisiin sisältyivät seuraavat asiat: opettajan antama oppimistehtävä ei mahdollista luovuuden käyttöä (18), oman tiedon ja kokemuksen puute liike-elämästä (4) ja omat aiemmat opiskelutavat ja -tottumukset (2).

Suurimmaksi koulutukselliseksi esteeksi koettiin se, että vaikka opintojaksojen tehtävänannot saavat opiskelijat ajattelemaan ja oppimaan, ne myös rajoittavat ja estävät luovuuden käyttöä. Tehtävät ovat liian usein yksitoikkoisia ja ikäviä, eivätkä ne motivoi luovuuden käyttöön. Myös koulun standardit ja opettajien asettamat rajoitukset tehtäville ovat esteinä. Usein myös kritisoidaan, jos poikkeaa tavanomaisista lähestymistavoista, eikä luovuuden käyttö tehtävissä myöskään johda hyviin arvosanoihin. Myös opiskelijoiden riittämättömät tiedot liike-elämästä estävät luovuuden hyödyntämisen, koska tällöin opiskelija ei pysty suhteuttamaan omaa luovuuttaan käytäntöön eikä pysty näkemään asioita eri näkökulmista. Opiskelijat kokevat omat aiemmat opiskelutavat ja -tottumukset vaivattomina ja uusista tavoista aiheutuva stressi on ollut esteenä ottaa uusia, mahdollisesti parempia tapoja käyttöön.

Sosiaalisina esteinä ilmeni epäonnistumisen pelko ja rohkeuden puute toteuttaa omaa luovuuttaan. Osa opiskelijoista pohti muiden ihmisten ennakkoluuloja ja odotuksia, osa kertoi pelkäävänsä osoittaa luovuuttaan, koska se yleensä merkitsee ongelmia, eivätkä he halua "vastustaa” koulun olemassa olevia käytänteitä.

\section{Luovuuden käytön lisäämis- mahdollisuudet opinnoissa}

Edellä esitetyistä esteitä ja rajoituksista huolimatta opiskelijat kertoivat erilaisista keinoista ja tavoista, miten he voisivat hyödyntää luovuutta enemmän opinnoissaan. Tulosten mukaan opiskelijat voivat halutessaan vaikuttaa itse luovuuden käyttöönsä, mutta myös muutokset kouluympäristössä ja nykyisissä käytänteissä edistäisivät luovuuden käyttöä.

Enemmistö opiskelijoista (22) kertoi voivansa lisätä luovuuden käyttöään uusien opiskelumetodien ja -tekniikoiden opettelulla ja käyttöönotolla. Osalle heistä jotkut luovat opiskelutekniikat ovat jo tuttuja. Kaikki kuitenkin painottivat omien opis- kelumetodien olevan liian perinteisiä ja myös rutiininomaisia. Opiskelijat kertoivat myös, että heidän tulisi muuttaa omaa ajatteluaan avoimemmaksi ja positiivisemmaksi uusille asioille ja muutoksille (9), hankkia lisää rohkeutta (5), kehittää riskin ottamisen ja epävarmuuden sietokykyään (5) ja hankkia aktiivisesti lisää tietoa liike-elämästä (4). Lisäksi luovuuden lisäämismahdollisuuksiin vaikuttavia tekijöitä olivat heidän mielestään uudenlaisen henkilökohtaisen opiskeluohjelman laadinta (3), opiskelu luovassa ympäristössä (3), keskustelut opiskelukaverin kanssa (3), muiden tarkkailu, miten he käyttävät luovuutta opinnoissaan (2), sosiaalisten verkostojen kehittäminen (2), uudenlaisten kurssien valinta ja suoritus oman ammatillisen osaamisen monipuolistamiseksi (2), opiskelukaverin kanssa yhdessä opiskelu tenttiä varten (1) sekä oman opiskelumotivaation kuntoon laittaminen (1).

Opiskelijoiden mukaan myös koulussa olevien, opiskeluun liittyvien käytänteiden ja toimintatapojen tulisi muuttua siten, että ne mahdollistavat ja kannustavat luovuuden käyttöön tarkoituksenmukaisella tavalla. Opiskelijat esittivät, että innovatiivisemmat tehtävät opintojaksoilla (3), lisää vapautta ja väljyyttä tehtävänantoihin (3) sekä nykyistä enemmän työelämälähtöisiä case-tehtäviä ja projekteja (3) lisäisivät mahdollisuutta luovaan ajatteluun ja luovaan ongelmanratkaisuun opinnoissa. Lisäksi suurempi määrä tiimityöskentelyä projekteissa (3) ja opettajan luovuuteen kannustava rooli (2) lisäisivät sitä. Kaiken kaikkiaan koulun tulisi kannustaa opiskelijoita enemmän luovaan ajatteluun ja ongelmanratkaisuun (1).

\section{Yhteenveto ja johtopäätökset}

Tapaustutkimukseni perusteella luovuus tarkoittaa eri asioita eri opiskelijoille ja luovuuden hyödyntäminen ilmenee eri tavoin. Kuitenkin opiskelijat ovat käyttäneet luovuuttaan useimmiten uusien opiskelutapojen löytämiseen ja nykyisten opiskelumetodien parantamiseen. Lisäksi he ovat käyttäneet luovuuttaan erilaisissa oppimistehtävissä ja projekteissa sekä yksittäisissä ongelmanratkaisutilanteissa. Hyödyntäessään luovuuttaan opiskelijat ovat ottaneet erilaisia riskejä mm. muiden ihmisten reaktioiden ja projektin lopputuloksen näkökulmasta.

Luovuuden hyödyntämiselle opinnoissa on sekä koulutuksellisia esteitä että sosiaalisia esteitä. Kaiken kaikkiaan opiskelijat voisivat lisätä luo- 
vuuden käyttöä opinnoissaan panostamalla itse uusiin opiskelumetodeihin, muuttamalla omaa ajattelutapaansa positiivisemmaksi, hankkimalla lisää rohkeutta, kehittämällä epävarmuuden ja riskinsietokykyään ja hankkimalla aktiivisesti lisää tietoa liike-elämästä. Tarvitaan myös muutoksia koulun nykyisiin käytäntöihin ja opettajien toimintatapoihin, jotta ne kannustaisivat ja tukisivat opiskelijoiden luovuuden käyttöä opinnoissa.

Saatujen kokemusten perusteella voidaan pohtia ja esittää joitakin alustavia johtopäätöksiä sekä opiskelijoiden ja opettajien että hieman laajemmin nykyisen kouluympäristön ja yrittäjyyskasvatuksen tavoitteiden näkökulmasta. Yksilön riskinottohalukkuus ja luovat aikaansaannokset liittyvät yhteen (Dewett 2004), joten opiskelija tarvitsee sekä rohkeutta että kannustusta uuden kokeiluun. Koska luovuus (mm. luova ongelmien ratkaisu, uusien mahdollisuuksien näkeminen) ja riski ovat keskeisimpiä yrittäjyyteen ja yrittäjämäiseen käyttäytymiseen liittyviä ilmiöitä, niiden käyttöä tulisi vahvistaa ja edistää yrittäjyyskasvatuksen keinoin.

Jos luovuus määritellään melko yleisesti kykynä tuottaa jotain uutta, erilaista ja käytännössä hyödynnettävää (Sternberg \& Lubart 2003), luovuutta voidaan hyödyntää hyvinkin eri tavoin opetuksessa. Tällöin periaatteessa ainoastaan opettajan oma aktiivisuus, kyky ja halukkuus ovat rajoina. Jos opettajan tavoitteena on työskennellä itse yrittäjämäisesti (ks. Paajanen 2001), haasteena lienee erityisesti se, kuinka kannustaa opiskelijoita luovuuden käyttöön silloin, kun se on mahdollista ja tarkoituksenmukaista, kuinka kehittää opiskelijoiden luovaa ajattelua ja ongelmanratkaisukykyä, kuinka rohkaista ottamaan hallittuja riskejä, kuinka kehittää samalla asiantuntemusta sekä auttaa näkemään uusia mahdollisuuksia ja nykyisiä asioita eri näkökulmista.

Koska uuden asian kokeiluun liittyy aina epävarmuutta, siihen liittyy myös onnistumisen tai epäonnistumisen mahdollisuus (ks. Koiranen \& Peltonen 1995), opettajilla pitäisi olla melko hyvä epävarmuudensietokyky hyödyntääkseen omaa luovuuttaan yrittäjyyskasvatuksessa. Itse asiassa tämä asia liittyy myös opiskelijoiden luovuuden käyttöön omissa opinnoissaan ja oppimisessaan: mitä enemmän opiskelijoilla on epävarmuudensietokykyä, sitä todennäköisemmin heillä on riskinsietokykyä (ks. Kyrö 2006).

Yrittäjyyskasvatus kohtaa luovuudessa useita haasteita riippumatta siitä, mitkä tavoitteet sillä kulloinkin on. Liiketalouden koulutusohjelmien opetussuunnitelmat laaditaan usein hyvin eksplisiittisesti ja ne sisältävät konkreettisia ja käytännönläheisiä oppimistavoitteita ja valmiuksia liiketalouden työtehtäviä varten. Mikäli yrittäjyyskasvatuksen tavoitteiksi asetetaan Ristimäen (2004b) mallin mukaan eri tasoja, luovuuden roolia tai tarvetta voidaan pohtia eri näkökulmista. Esimerkiksi jos yrittäjyyskasvatuksen tavoitteena pidetään ainoastaan kaupallisten aineiden opetusta, luovuuden tarve yrittäjyyskasvatuksessa lienee melko vähäinen. Mitä korkeammalle kyseisissä tasoissa edetään, sitä suurempi on sekä mahdollisuus että tarve hyödyntää luovuutta, koska yrittäjyyskasvatus ymmärretään tällöin laajasti koko kouluyhteisönä koskettavana ja yksilön yrittäjämäistä käyttäytymistä edistävänä asiana.

Edelleen, koska luovuus liittyy yleensä johonkin erityisalaan ja on osittain perinnöllistä, se lisää haastetta luovuuden käytölle yrittäjyyskasvatuksessa. Tällöin tulisikin pohtia yksityiskohtaisemmin, miten linkittää luovuus ja opiskelijoiden rajallinen toimialan tuntemus yrittäjyyskasvatuksen keinoin. Entä miten tukea ja kannustaa yksittäisten opiskelijoiden luovaa ajattelukykyä ja ongelmienratkaisukykyä oppimisessa?

Luovuus liittyy asiantuntijuuteen, luovaan ajatteluun ja motivaation luovuuden hyödyntämiseen (Amabile 2001). Ongelmallista on se, miten luovuus voidaan toteuttaa parhaiten jo opintojen aikana, jolloin tulevat asiantuntijat vasta opiskelevat noviiseina. Opiskelijan vähäinen kokemus ei rohkaise tai motivoi käyttämään mahdollisesti hänen hyvinkin luovaa ajattelukykyä opintojen alkuvaiheessa, mutta positiivisten kokemusten karttumisen myötä tilanne todennäköisesti jonkin verran muuttuu, jos olosuhteet ja oppimisympäristö sitä tukevat.

Luovuus vaatii aina aikaa ja vapautta, pakollisuus ei sovi sen yhteyteen. Luoviin prosesseihin liittyy aina epäonnistumisen riski, minkä vuoksi on tarpeen korostaa epäonnistumista sallivan ilmapiirin merkitystä. Tästä näkökulmasta luovuus, kekseliäisyys ja rohkeus niiden hyödyntämiseen liittyvät vahvasti yrittäjyyteen ja yrittäjämäiseen käyttäytymiseen ja luovuuden hyödyntäminen on todellinen haaste niin opettajille kuin opiskelijoillekin. Luovuuden eri haasteet yrittäjyyskasvatuksessa ovat moniulotteiset ja sisältävät monta eri tekijää. Kuinka niihin vastataan ja kuinka toimintaympäristöjä, opetusmenetelmiä ja -käytänteitä rakennetaan opiskelijoiden luovuutta tukevaksi, jää nähtäväksi. 


\section{Lähteet}

Amabile, T. M. (1997). Entrepreneurial creativity through motivational synergy. Journal of Creative Behaviour, 31(1), 18- 26.

Amabile, T. M. (2001). How to kill creativity. Teoksessa J. Henry (toim.) Creative Management. London, UK: Sage Publications. 2. p.

Amabile, T. M., Hadley, C. N. Kramer, J. (2003). Creativity under the gun. Harvard Business Review of Innovation Enterprise, 1- 25.

Csikszentmihalyi, M. (2003). Implications of the systems perspective for the study creativity. Teoksessa R. Sternberg (toim.) Handbook of Creativity, 313-335.

Dewett, T. (2004). Employee creativity and the role of risk. European Journal of Innovation Management, 7 (49), 257-266.

Gibb, A. (2005). The Future of Entrepreneurship Education - Determining the Basis for Coherant Policy and Practice. Teoksessa The Dynamics of Learning entrepreneurship in a Cross-Cultural University Context (P. Kyrö \& C. Carrier toim.). University of Tampere. Faculty of Education. Entrepreneurship Education Series 2/2005, 44-66.

Kets de Vries, M. (1991). Yritysmaailman sankarit ja häviäjät. Miksi yksi johtaja onnistuu ja toinen ei? Englanninkielisestä alkuteoksesta Prisoners of leadership. Suomentanut R. Liljamo. Hämeenlinna: Karisto Oy:n kirjapaino.

Kirby, D. (2004). Entrepreneurship education: Can business schools meet the challenge? Education + Training, 45 (8/9), 510-519.

Klandt, H, \& Volkmann, C. (2006). Development and Prospects of Academic Entrepreneurship Education in Germany. Higher Education in Europe, 31 (2), 195-208.

Ko, S. \& Butler, J. (2007). Creativity: A Key link to entrepreneurial behavior. Business Horizons, 50, $365-372$.

Koiranen, M. \& Peltonen, M. (1995). Yrittäjyyskasvatus. Tampere: Tammer-Paino Oy.

Koiranen, M. \& Ruohotie, P. (2001). Yrittäjyyskasvatus: analyyseja, synteesejä ja sovelluksia. Aikuiskasvatus, 21 (2), 102-111.

Kyrö, P. (1997). Yrittäjyyden muodot ja tehtävä ajan murroksessa. Jyväskylä Studies in Computer Science, Economics and Statistics 38.
Kyrö, P. (2001). Yrittäjyyskasvatuksen pedagogisia lähtökohtia pohtimassa. Aikuiskasvatus 21 (2), $92-101$

Kyrö. P. (2006). Avauksia riskin oppimiseen ja opetukseen. Teoksessa Kyrö. P. \& Ripatti, A. (toim.) Yrittäjyyskasvatuksen uusia tuulia. Yrittäjyyskasvatuksen julkaisusarja 4/2006. Tampereen yliopiston yliopistopaino. 98-130.

Kyrö, P. \& Ripatti, A. (2006). Yrittäjyyden opetuksen uudet tuulet. Teoksessa Kyrö. P. \& Ripatti, A. (toim.) Yrittäjyyskasvatuksen uusia tuulia. Yrittäjyyskasvatuksen julkaisusarja 4/ 2006. Tampereen yliopiston yliopistopaino. 10-31.

Leskinen, P.-L. (1999). "Yrittäjällä on koko elämä kiinni yrityksessään”. Opiskelijoiden yrittäjyyskäsitykset ja niiden muutokset yritysprojektin aikana. Vaasan yliopisto.

Luukkainen, O. \& Wuorinen, J. (2002). Yrittävä elämänasenne. Kasvaminen yksilönä ja yhteisönä. Jyväskylä: PS-kustannus.

Paajanen, P. (2001). Yrittäjyyskasvattaja. Ammattikorkeakoulun hallinnon ja kaupan alan opettajien näkemykset itsestään ja työstään yrittäjyyskasvattajana. Jyväskylän yliopisto.

Paasio, K. \& Nurmi, P. (2006). Yliopistolliset yrittäjyysopinnot Suomessa. Teoksessa Kyrö, P. \& Ripatti, A. (toim.) Yrittäjyyskasvatuksen uusia tuulia. Yrittäjyyskasvatuksen julkaisusarja 4/2006, Tampereen yliopiston kauppakorkeakoulu, Hämeenlinna, 32-37.

Ristimäki, K. (2004a). Yrittäjäksi identifioituminen. Fenomenologis-hermeneuttinen tutkimus nuorten yrittäjyyteen liittyvän identiteetin kehityksestä. Vaasan yliopisto.

Ristimäki, K. (2004b). Yrittäjyyskasvatus. Järvenpää: Yrityssanoma Oy.

Ruohotie, P. (1998). Motivaatio, tahto ja oppiminen. Helsinki: Oy Edita Ab.

Sternberg, R. \& Lubart, T. 2003. The Concept of Creativity: Prospects and paradigms. Teoksessa R. Sternberg (toim.) Handbook of Creativity. 3-15.

Tuomivaara, S., Hynninen, K., Leppänen, A., Lundell, S. \& Tuominen, E. (2005). Asiantuntijan luovuus koetuksella. Työterveyslaitos. 